\title{
Oxygen reduction approaches for fire protection to increase grid Li-ion BESS safety
}

\author{
Linda Barelli ${ }^{1 *}$, Gianni Bidini ${ }^{1}$, Federico Gallorini ${ }^{2}$, Panfilo A. Ottaviano ${ }^{1}$, Dario Pelosi ${ }^{1}$, Michele Perla ${ }^{1}$, Monica \\ Serangeli ${ }^{2}$ \\ ${ }^{1}$ Department of Engineering, University of Perugia, Via G. Duranti 93, Perugia 06125, Italy \\ ${ }^{2}$ VGA. S.r.l., Via U. Foscolo 1, San Nicolò di Celle - Deruta (PG) 06053, Italy
}

\begin{abstract}
Li-ion battery is the most diffused technology among electrochemical energy storage systems. Installed capacity forecasts suggest a strong growth in the next years with renewable energy utilization to meet decarbonization purposes. Over 20 fire incidents in grid systems where reported during the last years in Korea and United States, with negative repercussions in market and social acceptance. Thermal runaway results as the recurring high impact failure effect. A novel concept to prevent $\mathrm{Li}$-ion battery fires in grid installations could be represented by the realization of an oxygen-deficient atmosphere inside the containers. This novel approach is presented and discussed with reference to the framework of battery fire protection and the application of oxygen reduction.
\end{abstract}

Keywords: energy storage; Li-ion batteries; regulatory issues; system safety; oxygen reduction systems

\section{Introduction}

Battery energy storage systems (BESS) had a strong growth in Italy since 2013. National tax deductions and incentive systems for the coupling with photovoltaic plants up to $20 \mathrm{~kW}$, increased residential size plants installations up to over 18.000 units in the beginning of 2019 [1]. The wind power curtailment, due to grid criticalities, reached $436 \mathrm{GWh}$ in 2017 [2] and, consequently, Terna S.p.A., the Italian transmission system operator, installed utility scale BESS near the critical transmission lines[3]. Li-ion batteries are the world's most used in electrochemical storage, amounting at $1.3 \mathrm{GW}$ installed power in 2017. Events of Li-ion grid BESS fire and explosion happened in USA [4] and South Korea [5] with remarkable impact in sales, reported by cells producers. Li-ion is a mature technology, product standardization and safety systems for batteries are established, despite of that several incidents occurred. A scenario of increase of Li-ion BESS installations is very likely; facing safety issues can prevent repercussions in the social sphere and market. In order to increase fire protection effectiveness, the application of oxygen reduction system (ORS) is here discussed.

\section{Li-ion BESS thermal runaway}

Fire or explosion in Li-ion BESS facilities involved plants with size from 1.5 to 40 MW. 23 BESS fires were reported in Korea during 2018 [5]. An investigation committee identified inadequate facility installation and management issues, also system level control problems in abuse state check and cell level construction defects. The government suspended the operations of 522 over 1,490 energy storage facilities in the country. Market repercussions for main cells manufacturers showed an operative income drop over $50 \%$ in the first quarter of 2019, moreover fire damage coverings are estimated to be over $90 \mathrm{M€}[6]$.

The first US incident happened in 2012 in Flagstaff (AZ), at the 1.5 MW Electrovaya storage system. The cause was attributed to battery overcharge due to energy management system failure. Inadequate electric circuit protection and temperature sensors issues were also found [7]. A second event happened in 2019 in McMicken (AZ), AES-Siemens Fluence 2MW/2MWh facility owned by Arizona Public Service was involved in a fire and subsequent explosion as the firefighters opened the container. The monitoring systems detected

\footnotetext{
* Corresponding author: linda.barelli@unipg.it
} 
a voltage drop across the modules of one particular rack, followed by an increase in temperature; the fire didn't spread to the surrounding racks. Subsequent forensic analysis stated that one single battery rack thermal runaway started the fire, the cause of explosion is still under investigation. Anyway, no vent system was present in the container [8]. A possible cause of the blast could be the presence of flammable gas, heat sources and the lack of oxygen, previously consumed by the battery fire. Hence, when first responders opened the container door a "backdraft" type explosion occurred. Investigations are still undergoing. This event led to safety concerns about Li-ion BESS: a 100 MW/200 MWh project by Enel Greenpower Inc in Littleton (NH) found local opposition and social acceptance is still an issue in the permitting process [9].

Nickel-Manganese-Cobalt oxide (NMC), LithiumIron-Phosphate (LFP) and Lithium-Cobalt oxide (LCO) are the most used materials for cathodes, while the most commercially used anode material is Carbon-Graphite (C). Exothermic reactions can occur in Li-ion batteries causing a self-overheating process called "thermal runaway". It leads to battery fires and under certain conditions to explosions. The root causes may be mechanical abuse, thermal abuse, electrical abuse and internal construction defects, implying internal short circuit (ISC), but also charger or battery management system (BMS) failures.

Activation temperature was measured, depending on open circuit voltage (OCV), $104 \div 144^{\circ} \mathrm{C}$ as reported in [10], and cathode chemistry (e.g., $246^{\circ} \mathrm{C}$ for a LFP [11]).

Oxygen is released in small quantities from the cathode during its degradation and it is also contained in solvent materials. This content is not sufficient to the complete combustion of electrolyte and other materials [12] and effect on combustion and heat release rate can be considered negligible [13]. A sharp voltage drop occurs 15-40 s before the self-heating [11], hence an effective shut down operation can't be operated. Gas generation occurs during thermal runaway; it can lead to fires reacting with ambient air oxygen. Vent gas mixture composition in inert atmosphere is reported in Table 1 depending on cell chemistry.

Table 1. Vent gas mixture compositions from 18650 cells thermal runaway in inert atmosphere [14]

\begin{tabular}{|c|c|c|c|}
\hline & LCO/NMC & NMC & LFP \\
\hline $\mathrm{H}_{2}[\%]$ & 30 & 30.8 & 30.9 \\
\hline $\mathrm{CO}_{2}[\%]$ & 24.9 & 41.2 & 53 \\
\hline $\mathrm{CO}[\%]$ & 27.6 & 13 & 4.8 \\
\hline $\mathrm{CH}_{4}[\%]$ & 8.6 & 6.8 & 4.1 \\
\hline $\mathrm{C}_{2} \mathrm{H}_{4}[\%]$ & 7.7 & 8.2 & 6.8 \\
\hline $\mathrm{C}_{2} \mathrm{H}_{6}[\%]$ & 1.2 & - & 0.4 \\
\hline
\end{tabular}

\section{Li-ion BESS thermal runaway}

State of the art safety measures in BESS are working at different levels: a polymer porous structure separator is used to prevent ISC, moreover it provides a shutdown in case of temperature rise through melting. Flame retardants are added to the electrolyte and separator to contain a fire extension from cell to cell. A fail-safe mechanism is applied in prismatic and cylindric cells to limit pressure rise using safety vents, releasing the flammable gases. The BMS limits the battery operation within a safety range, providing also ISC detection. Utility scale Li-ion BESS adopt automated fire detection and suppression systems. Extinguishing agents were evaluated during firefighting tests on portable, stationary and electric vehicle (EV) batteries, showing the high effectiveness of water, providing high cooling effect [15-17]. This mechanism is fundamental to prevent reignition of cells vent gas which has been reported even $22 \mathrm{~h}$ after flame extinguishing. On the contrary, a massive amount of water is needed to complete firefighting procedures, up to $10 \mathrm{~m}^{3}$ in a EV test [17]. Battery shells and enclosures limit the action of water; moreover, the sprinkler system action can trap vent gases in high concentration volumes rising explosion risk [18]. The use of water as extinguishing agent in case of a fire caused by a thermal runaway event in a single module fire implies the whole equipment damaging, hence the application in grid BESS is not convenient.

A typical fire suppression system is activated through the first smoke detection, with a subsequent electrical shutdown; a second detection activates the flooding of fire suppression agent, fluorinated ketone not harmful for electrical equipment. A water spray system is activated by first responders to complete the firefighting procedure, the container is protected from explosion pressure by deflagration vents [19]. Another configuration is based on infrared and blue led sensor detection coupled with $\mathrm{N}_{2}$ agent [20]. Other agents are also used, such as heptafluoropropane, hybrid $\mathrm{N}_{2}$ /water mist and potassium nitrate aerosol [21]. Early fault detecting systems based on gas emission detection have been developed, adopting 0-100 ppm gas sensors [22], capable of response avoiding thermal runaway by module shut-down.

This work for the first time investigates the application of ORS in Li-ion BESS. The concept aims to create an inert ambient in the battery room/enclosure through oxygen adsorption, avoiding the risk of explosive atmosphere formation and thermal runaway propagation.

BESS are not directly addressed in Italian safety regulations. When included in activities subject to authorization, the authority having jurisdiction considers these systems as a specific risk area/entity. In these cases the application of Interior Ministry Decree $03 / 05 / 2015$ [23] requires a specific evaluation of safety measures such as separation, fire detection, automatic fire suppression, fault and failure supervision, hazard substances release prevention.

In order to diffuse knowledge and awareness of Liion BESS safety aspects, the National Fire Rescue and 
Service (CNVVF) and the Italian National Agency for New Technologies, Energy and Sustainable Economic Development (ENEA) published a complete study including all the necessary elements at the state of the art [24], allowing a performance-based fire safety design in the absence of a specific regulation. Moreover, $\mathrm{Li}$-ion technology can be considered more convenient in energy storage plants authorization procedure, if compared to Na-S. Indeed, this last technology involves Seveso Directive duties as reported by Terna S.p.A. field experience [25].

\section{Oxygen reduction fire protection systems}

ORS concept aims to create a protected area to prevent a fire start or spreading. The level of oxygen reduction depends on the proper balance between atmosphere inerting and risk level in the specific area, taking into account personnel safety.

The application is therefore subjected to compliance with national laws, e.g. Italian legislation defines the risk of asphyxiation for $\mathrm{O}_{2}$ concentrations lower than $19.5 \%$ with different damage levels and lethal consequences down to $4 \div 8 \%$. The $\mathrm{N}_{2}$ rich mixture, needed to create the oxygen-deficient atmosphere, can be provided by a nitrogen generator or cylinder pack; an oxygen monitoring system is then fundamental to control if room conditions respect the limits cited above. ORS systems are mostly used in areas where availability and service continuity are needed, such as hospitals power factor correction rooms, operating theaters main switch rooms, data centers and computer rooms. They are also installed in cold storage warehouses, hazardous materials storage, museums, archives and heritage protection [26]. $\mathrm{O}_{2}$ design concentration in occupied spaces is between 14 and $16 \%$, while in automated warehouses it can be as low as 13\% [27]. References for oxygen inerting concentration mention Limiting Oxygen Concentration (LOC) for various fuels. For most of them a value of $10 \%$ can prevent ignition except for carbon disulfide $(5 \%)$, carbon monoxide $(5.5 \%)$, hydrogen $(5 \%)$, hydrogen sulfide $(7.5 \%)$ and aluminium (5\%) [28]. As previously reported in Table 1, some of these species are contained in thermal runaway emissions mixtures.

A limited oxygen production occurs during thermal runaway; it is consumed with insignificant heat release, despite that, flammability conditions can't be avoided because of its presence inside a cell subjected to thermal runaway. The principle of operation of automated inert gases extinguishing systems, such as $\mathrm{N}_{2}$ based ones, is the generation of a hypoxic atmosphere after the fire detection. In order to improve fire protection effectiveness, an alternative strategy is here proposed, keeping the oxygen concentration below vent gas LOC. Thus, the extension of thermal runaway fire is limited to the first cells involved, avoiding fire in adjacent cells and equipment destruction consequences. Moreover, BESS availability after a thermal runaway event is enhanced if compared to water fire suppression systems, avoiding devices damages.

\section{Limiting Oxygen Concentration for vent gas fire control}

The choice of the ORS ignition threshold to protect a Liion BESS can be made focusing on thermal runaway vent gas. Lower flammability limits for cells vent gas can be calculated, based on the Le Chatelier rule, according to ISO 10156 4.5.3. [29]. Results are reassumed in Table 2.

Table 2. Cells vent gas lower flammability limits

\begin{tabular}{|c|c|}
\hline $\begin{array}{c}\text { VENT GAS } \\
\text { MIXTURE }\end{array}$ & LFL $_{\text {mix }}(\%)_{\mathrm{vol}}$ \\
\hline LCO/NMC & 6.4 \\
\hline NMC & 7.3 \\
\hline LFP & 8.4 \\
\hline
\end{tabular}

The mixture resulting from $\mathrm{LCO} / \mathrm{NMC}$ is the most dangerous according to the calculated LFL values. Moreover, LCO/NMC pouch cells vent gas volume emissions were reported to be $0.78 \mathrm{~m}^{3} / \mathrm{kg}$, the highest value if compared to LFP $\left(0.042 \mathrm{~m}^{3} / \mathrm{kg}\right)$ [30]. Fuel mixture LOC calculation can be provided through the method expressed by eq. (1) and proposed by Zlochower et al. [31], in analogy with Le Chatelier rule for Lower Flammability Limit (LFL).

$$
L O C=\sum X_{i} R_{i} / \sum X_{i} R_{i} /(L O C)_{i}
$$

Table 3. LOC values [20]

\begin{tabular}{|c|c|}
\hline GAS & LOC $(\%)_{\text {vol }}$ \\
\hline $\mathrm{H}_{2}$ & 5 \\
\hline $\mathrm{CO}$ & 5.5 \\
\hline $\mathrm{CH}_{4}$ & 12 \\
\hline $\mathrm{C}_{2} \mathrm{H}_{4}$ & 10 \\
\hline $\mathrm{C}_{2} \mathrm{H}_{6}$ & 11 \\
\hline
\end{tabular}

Where $X_{i}$ is the molar fraction of the combustible component, $R_{i}$ is the stoichiometric oxygen to fuel ratio, and $(L O C)_{i}$ is the value for component $i$ as reported in Table 3. This method is conservative because inert gas heat capacity in the mixture is not considered. Calculated LOC values for Li-ion thermal runaway vent gas mixtures are reported in Table 4. 
Table 4. Vent gas calculated LOC

\begin{tabular}{|c|c|}
\hline $\begin{array}{l}\text { VENT GAS } \\
\text { MIXTURE }\end{array}$ & LOC $_{\text {mix }}(\%)_{\text {vol }}$ \\
\hline LCO/NMC & 7.60 \\
\hline NMC & 7.65 \\
\hline LFP & 7.5 \\
\hline
\end{tabular}

Considering the presence of $\mathrm{CO}_{2}$ in the vent gas mixture, as reported in Table 1, and according to LFL ISO 10156, oxygen calculation would lead to significant values increase if compared to the same mixture containing only combustible components. It results that worst-case mixture is produced by LFP cells, $\mathrm{O}_{2}$ maximum concentration is set at $6.7 \%$ including a safety margin ($0.75 \%$ ) recommended by EN 16750 applied to the values in Table 4. Effect of reduced oxygen atmosphere on Li-ion batteries thermal runaway has been reported by Kunkelmann [32], reducing flame duration (min:sec) from $0: 43 \div 2: 49$ in normal atmosphere to only 00:03 00:05 when oxygen concentration is $8 \%$ in $\mathrm{N}_{2}$.

\section{Conclusions}

This work proposes a new concept in prevention and protection of Li-ion BESS. Main advantages are the supposed effectiveness in fire control if compared to other systems, avoiding the typical fast fire spreading in thermal runaway events. Low oxygen levels, down to $6.7 \%$, must be reached to avoid thermal runaway effects such as fire and explosions, hence personnel access in the protected area can be allowed only by mandatory protection devices utilization. The recent incidental experience had impact in market and social perception of a fundamental technology for energy transition, mostly because of fire events magnitude and the first responders injured. This novel concept can contrast both drivers of this phenomenon. Moreover, this kind of system can enhance BESS availability in case of fire events, since i) it limits failure consequences, ii) it allows the substitution of damaged module elements and, therefore, iii) it avoids total equipment lost, with risk related cost saving.

\section{References}

1. Federazione ANIE - Confindustria, Osservatorio sistemi di accumulo (dati al 31 Marzo 2019) - sistemi di accumulo in Italia - $i$ primi dati, (2019). https://anie.it/wpcontent/plugins/acd-attach-document/acd-getdocument.php?post_ID $=47468 \&$ file_name $=$ cssistemi-di-accumulo_24-09-19.pdf

2. ARERA, Stato di utilizzo e di integrazione degli impianti di produzione alimentati dalle fonti rinnovabili anno 2017, (2018) 76 https://www.arera.it/allegati/docs/18/42818.pdf

3. Terna S.p.A., Rapporto mensile sul sistema elettrico, Ottobre 20 (2017) 1-37.

https://www.terna.it/it-

it/sistemaelettrico/dispacciamento/datiesercizio /rapportomensile.aspx

4. J. Spector, What We Know and Don't Know About the Fire at an APS Battery Facility, April 23. (2019).

https://www.greentechmedia.com/articles/read/ what-we-know-and-dont-know-about-the-fireat-an-aps-battery-facility (accessed November 4, 2019)

5. S. Ji-hye, Panel blames electric shock, poor management system for ESS fires, not companies, 16 June. (2019).

http://www.koreaherald.com/view.php?ud=201 90611000679 (accessed January 13, 2020)

6. Yonhap news agency, (LEAD) ESS makers take a hit from delayed probe into fires, 2 May. (2019).

https://en.yna.co.kr/view/AEN2019050200105 1320

7. J. Weaver, Regulator says lithium-ion batteries create "unacceptable risks," 8 August. (2019). https://pv-magazineusa.com/2019/08/08/lithium-ion-not-prudentand-create-unacceptable-risks/

8. J. Spector, The Arizona Battery Explosion Is Changing Conventional Wisdom on Safety, 10 Oct. (2019).

https://www.greentechmedia.com/articles/read/ arizona-battery-explosion-conventionalwisdom-safety (accessed January 13, 2020)

9. Littleton New Hampshire Municipality, Approved Zoning Board Minutes, 10 December. (2019).

http://www.townoflittleton.org/meeting/1531/ Approved-Zoning-Board-Minutes-December10-2019.

10. S. Al Hallaj, H. Maleki, J.S. Hong, J.R. Selman, Thermal modeling and design considerations of lithium-ion batteries, J. Power Sources. 83 (1999) 1-8. https://doi.org/10.1016/S0378-7753(99)001780

11. G. Guo, B. Long, B. Cheng, S. Zhou, P. Xu, B. Cao, Three-dimensional thermal finite element modeling of lithium-ion battery in thermal abuse application, J. Power Sources. 195 (2010) 2393-2398

https://doi.org/10.1016/j.jpowsour.2009.10.090

12. TOTAL BATTERY CONSULTING Inc., "The battery safety and abuse tolerance report," 2016

13. Y. Fu, S. Lu, K. Li, C. Liu, X. Cheng, H. Zhang, An experimental study on burning behaviors of 18650 lithium ion batteries using a cone calorimeter, J. Power Sources. 273 (2015) 216-222

https://doi.org/10.1016/j.jpowsour.2014.09.039

14. A.W. Golubkov, D. Fuchs, J. Wagner, H. 
Wiltsche, C. Stangl, G. Fauler, G. Voitic, A. Thaler, V. Hacker, Thermal-runaway experiments on consumer $\mathrm{Li}$-ion batteries with metal-oxide and olivin-type cathodes, RSC Adv. 4 (2014) 3633-3642 https://doi.org/10.1039/c3ra45748f

15. US Department of Transportation - Federal Aviation Administration, Extinguishment of Lithium-Ion and Lithium-Metal Battery Fires, 2017.

16. P. Russo, C. Di Bari, M. Mazzaro, A. De Rosa, I. Morriello, Effective fire extinguishing systems for lithium-ion battery, Chem. Eng. Trans. 67 (2018) 727-732. https://doi.org/10.3303/CET1867122

17. R.T. Long Jr., A.F. Blum, T.J. Bress, B.R.T. Cotts, H.R.R.T. The, T. Observations, A.. Fallis, Best Practices for Emergency Response to Incidents Involving Electric Vehicles Battery Hazards $\square$ : A Report on Full-Scale Testing Results, J. Chem. Inf. Model. 53 (2013) 1009-1010. https://doi.org/10.1017/CBO9781107415324.0 04

18. DNV GL, Technical Reference for Li-ion Battery Explosion Risk and Fire Suppression, 2019

19. NEC Energy Solutions, Fire detection and suppression, 2019

20. Siemens, Fire protection for Li-ion battery energy storage systems, (2019) 1-18

21. DNV GL Energy, Testing of Aerosol Fire Extinguishing Agent for Li-ion Battery Fires, 2017

22. D. Hill, B. Gully, A. Agarwal, A. Nourai, L. Thrun, S. Swartz, M. Koslowske, S. Cummings, J. Butkowski, B. Moore, Detection of off gassing from Li-ion batteries, 2013 IEEE Energytech, Energytech 2013. (2013) 1-7. https://doi.org/10.1109/EnergyTech.2013.6645 307

23. Italian Ministry of the Interior, DM 03/08/2015 - Approvazione di norme tecniche di prevenzione incendi, ai sensi dell' articolo 15 del decreto legislativo 8 marzo 2006, n. 139., (n.d.)

24. CNVVF, ENEA, Rischi connessi con lo stoccaggio sistemi di accumulo Litio-ione, 2019

25. M. Rebolini, S. Tosi, R. Vanadia, N. Di Pietro, E. Senatore, R. Polito, The authorization procedure for Energy Storage Systems Projects installed on the Italian Transmission Grid, in: CIGRE', 2016

26. G. Jensen, J. Holmberg, A. Gussias, M. Melgard, Hypoxic Air Venting for Protection of Heritage, 2006

27. ISOLCELL S.p.A., (n.d.). https://www.n2ors.com/it/applicazioni/somecase-histories/ (accessed January 16, 2020)

28. P. Berg, A. Lindgren, Fire Prevention and Health Assessment in Hypoxic Environment, 2004
29. European Commitee for Standardization, Gas cylinders - Gases and gas mixtures Determination of fire potential and oxidizing ability for the selection of cylinder valve outlets ISO10156, (2017)

30. D. Sturk, L. Rosell, P. Blomqvist, A. Ahlberg Tidblad, Analysis of Li-Ion Battery Gases Vented in an Inert Atmosphere Thermal Test Chamber, Batteries. 5 (2019) 61. https://doi.org/10.3390/batteries5030061

31. I.A. Zlochower, G.M. Green, The limiting oxygen concentration and flammability limits of gases and gas mixtures, J. Loss Prev. Process Ind. 22 (2009) 499-505. https://doi.org/10.1016/j.jlp.2009.03.006

32. J. Kunkelmann, Studie zur Brandbekämpfung von Lithium-Ionen-Batterien (Akkus) und Lithium-Metall-Batterien, 2017 